\title{
David as a Map
}

\author{
Guntram H. Herb \\ Department of Geography \\ Middlebury College
}

\author{
Ph.D. 1992, University of Wisconsin, Madison \\ National Self-determination, Maps and Propaganda in \\ Germany, 1918-1945
}

$\mathrm{W}$ hen I think of David Woodward, I think of a map. It is an extraordinary map. For in David's view, there was no such thing as an "ordinary" map and David was an exceptional human being. This map has a special place in my heart. It has guided me and continues to guide me through perilous voyages of discovery: my research, my professional career, and my personal life. It gave me a baseline from which to start, it helped me orient my endeavors, and it clearly depicted the peaks that I should aspire to reach as well as the treacherous passages I should evade.

What are the dimensions of this map? Don't think of it in two or even three dimensions and don't even try looking for a border. David's intellectual curiosity and imagination were not constrained by conventions. His spirit soared far beyond the Euclidian grid. His map's scale is flexible and dynamic. When David and his friend, the late Brian Harley, first conceived of the History of Cartography project, they envisioned three or four volumes, but soon it grew to six. Once work got under way, the individual volumes grew so much that some had to be split into two or three books. For David, scale was not pre-defined, but intimately tied to the goals he set for himself-and David had big plans. He never tired or lost sight of his vision. When financing became tough with major budget cuts for funding agencies, he didn't despair; he just looked for new sources. Whenever I faced a major challenge, I thought of David's response to adversity: "there is always another way..."

What kind of artifact is this map? If you have ever seen an original map from the Renaissance-David's favorite historical period-you should have an idea of its artistry, beauty, and scientific sophistication. David was not only a renowned scholar, but a superb cartographer, craftsman and designer. His penmanship would have earned him respect even among the scribes of the Islamic world where calligraphy was cherished. His maps and sketches were striking and the broadsheets he printed for the friends of the History of Cartography project were stunningly beautiful compositions that integrated text and image. Just like the pieces he created, David's map is a synthesis of art and analysis. He was at home and happy in the archive as well as the print shop, the class room as well as outdoors, and even in the air-he obtained a pilot license a few years ago and was passionate about flying. Looking at David's map makes me realize that happiness means walking different paths-and that narrow specialization is something to be avoided.

What is my favorite part of this map? I could not single out one element for it would do injustice to the sweeping influence David's map has had on me. Its projection is multifaceted and conveys wisdom, warmth, ethics, and humor. Yet, I will elaborate on the sense of humor since David was not inclined to end on a sad note. I fondly remember David's comments on papers, often illustrated with a succinct image and always with beautiful penmanship and wit. The best example I can think of is the comment he wrote on one of Kevin Kaufman's papers. Kevin's statement, the "scale found its way on the map" was brilliantly critiqued with the 
drawing of a scale as a caterpillar that moved towards a map. The same dazzling wit comes out in David's excursion into bovine cartography. $\mathrm{He}$ gave brilliant and hilarious lectures on the scientific controversy over the map-like, black-spots on Holstein cows and put it in practice by painting a map of Wisconsin directly on a cow. A photo of this "Wisconsin geography" graces my favorite coffee mug. I proudly bring the mug-and along with it the spirit of the remarkable man that conceived it-to every class I teach at Middlebury College.

P.S.: I should tell you that no animals were hurt in the creation of the map of Wisconsin. Rumor has it that the embellished cow became a celebrity among her fellow bovines. She is also credited with putting body art on the map.

\section{In Memory of David Woodward, Schol- ar and Mentor}

\author{
Ph.D. 1994, University of Wisconsin, Madison \\ Mapping the United States-Mexico Boundary, \\ 1849-1857
}

I am deeply honored to write in memory of David Woodward, and I thank Cartographic Perspectives and Scott Freundschuh (and Matthew Edney for putting Scott in touch with me) for inviting me to contribute to this special issue on the accomplishments of Professors Arthur Robinson and David Woodward. I was privileged to meet Arthur Robinson when I was a student and he was a guest speaker in a graduate seminar in cartography taught by David Woodward. It was my great privilege to be a student of David Woodward's. David was my Ph.D. adviser and my mentor, and above all, my model as a scholar.

In my memory, I am most likely to see David seated at his desk in his office, the setting for graduate student consultations. His office was in an angle of the fourth floor of the University of Wisconsin-Madison's venerable Science Hall. An odd-shaped room, it had the feel of a garret in a medieval turret, especially with its metal staircase spiraling up to a balcony inside the office. It was a crowded room, filled with books in bookcases reaching from floor to ceiling ("I like books," I recall David saying one time when I talked with him in his office, "I just like having them around $\left.\mathrm{me}^{\prime \prime}\right)$ and piles of papers covering desk and shelves and filing cabinets. The balcony was filled with more books, a microforms reader, and boxes of papers and past projects. On shelves near his desk, in neat stacks, were reprints of articles he had written. In his office, surrounded by his library and archives of the history of cartography, David seemed most at home.

David's intense interest in the history of cartography followed from his early experience as a cartographer. My own interest developed according to a similar pattern; as I began my PhD program in the history of cartography at the University of Wisconsin-Madison, after completing my MS in applied cartography and working as a cartographer at Northern Illinois

\author{
Paula Rebert \\ Albuquerque, NM
}

